\title{
PEMANFAATAN LIMBAH PADAT INDUSTRI TEPUNG TAPIOKA DAN INDUSTRI TAHU SEBAGAI BAHAN BAKU BIOETANOL DENGAN PROSES HIDROLISA $\mathrm{H}_{2} \mathrm{SO}_{4}$ DAN FERMENTASI RAGI INSTAN
}

\section{UTILIZATION OF TAPIOCA AND TOFU INDUSTRIAL SOLID WASTE AS BIOETHANOL RAW MATERIAL WITH $\mathrm{H}_{2} \mathrm{SO}_{4}$ HYDRAULIC PROCESS AND INSTANT FERMENTATION}

\author{
Nanti Musita \\ Balai Riset dan Standardisasi Industri Bandar Lampung \\ Jl. By Pass Soekarno-Hatta Km.1. Rajabasa. Bandar Lampung \\ Email : nantimusita@gmail.com
}

\begin{abstract}
ABSTRAK
Jumlah limbah padat dari industri tepung tapioka dan industri tahu cukup melimpah, namun belum dimanfaatkan secara optimal. Padahal bahan tersebut masih mengandung karbohidrat cukup tinggi sehingga dapat dimanfaatkan sebagai bahan baku pembuatan bioetanol. Pada penelitian ini dilakukan pembuatan bioetanol dari limbah padat (onggok) industri tapioka dan industri tahu. Penelitian ini bertujuan untuk mendapatkan konsentrasi asam sulfat optimum pada proses hidrolisa dan waktu fermentasi optimum pada proses pembuatan bioetanol dari onggok tapioka dan onggok tahu. Hasil penelitian menunjukkan bahwa onggok tapioka dan onggok tahu dapat dimanfaatkan sebagai bahan baku pembuatan bioetanol. Konsentrasi asam sulfat yang optimum untuk menghidrolisa onggok tahu dan tapioka pada konsentrasi $0,5 \mathrm{M}$ selama 30 menit suhu $121^{\circ} \mathrm{C}$. Selama fermentasi berlangsung terjadi penurunan $\mathrm{pH}$ dan glukosa serta peningkatan produksi etanol. Produksi etanol optimum terjadi pada lama fermentasi 5 hari dengan konsentrasi etanol 4,77\% b/b dari onggok tahu dan 4,97\% b/b dari onggok tapioka.
\end{abstract}

Kata kunci : bioetanol, industri tahu, industri tepung tapioka, hidrolisa, ragi instan

\begin{abstract}
The amount of solid waste from tapioca flour industry and tofu industry is quite abundant, but it has not been used optimally. Even though the material still contains enough high carbohydrates so that it can be used as a raw material for bioethanol. Bioethanol of the study made from solid waste (onggok) of tapioca industry and tofu industry. The objects of the study to obtain the optimum concentration of sulfuric acid in the hydrolysis process and to obtain the optimum fermentation time in the process of making bioethanol from onggok of tapioca industry and tofu industry. The result of the research exhibited that onggok of tapioca and onggok of tofu can be used as raw material for making bioethanol. The optimum concentration of sulfuric acid to onggok of tofu and tapioca on hydrolysis process at a concentration of $0.5 \mathrm{M}$ for 30 minutes at $121^{\circ} \mathrm{C}$. While fermentation process, there are decreasing process in $\mathrm{pH}$ and glucose, then increasing ethanol production. The optimum ethanol production occurs at 5 days fermentation time with ethanol concentration of $4.77 \% \mathrm{~b} / \mathrm{b}$ from onggok of tofu and $4.97 \%$ $b / b$ from onggok of tapioca.
\end{abstract}

Keywords: bioethanol, tofu industry, tapioca flour industry, hydrolysis, instant yeast 


\section{PENDAHULUAN}

risis energi dunia merupakan masalah yang sedang dihadapi banyak negara di dunia termasuk Indonesia. Krisis ini terjadi akibat ketergantungan pemenuhan energi bahan bakar dunia yang berasal dari bahan bakar fosil. Sedangkan bahan bakar fosil merupakan sumber daya alam yang tidak dapat diperbaharui dan ketersediaannya di dunia sangat terbatas.Data Dirjen Minyak dan Gas Kementerian ESDM RI menyebutkan bahwa saat ini Indonesia memiliki cadangan minyak bumi sekitar 3,17 Miliar Barel (remaining reserved). Dengan produksi sekitar 800.000 ribu Barrel per hari, maka jika tidak ditemukan cadangan yang baru, minyak bumi diperkirakan akan habis dalam 10 tahun. Cadangan gas bumi mencukupi untuk 49 tahun ke depan, dan cadangan batubara sebesar 37 miliar akan bertahan hingga sekitar 76 tahun ke depan jika tidak ada eksplotasi (Dirjen Minyak dan Gas, 2018). Oleh karena itu sangat diperlukan usaha-usaha pencarian energi alternatif yang dapat dipertimbangkan untuk mengatasi krisis energi yaitu bioetanol.

Penggunaan energi dari bahan bakar fosil akan menyisakan residu yang memberikan dampak pada pencemaran lingkungan dan peningkatan suhu bumi. Penggunaan bahan bakarfosil menyumbang emisi gas rumah kaca $\left(\mathrm{CO}_{2}\right)$ sebesar $76 \%$ yang terdiri dari proses industri $65 \%$ dan kehutanan beserta penggunaan lahan lainnya $11 \%$. Pemakaian bahan bakar bensin dan solar pada kendaraan bermotor juga menghasilkan $\mathrm{CO}_{2}$. Jumlah kendaraan bermotor yang semakin meningkat berbanding lurus dengan peningkatan emisi $\mathrm{CO}_{2}$. Pada tahun 2014 dihasilkan 126,56 juta ton, yang terdiri dari 69,63 juta ton emisi $\mathrm{CO}_{2}$ dari pemakaian bahan bakar bensin dan 56,92 juta ton emisi $\mathrm{CO}_{2}$ dari pemakaian solar (Badan Pusat Statistik, 2016).

Terkait dengan permasalahan energi dan efek gas rumah kaca tersebut di atas, pengembangan bioenergi dapat menjadi alternatif solusinya. Keuntungan dari penggunaan bioenergi adalah dapat mengurangi emisi gas rumah kaca di seluruh siklus hidup bioenergi. Penggunaan biomassa untuk memproduksi biofuel, seperti etanol terbukti dapat mengurangi emisi $\mathrm{CO}_{2}$ jika dibandingkan dengan produksi bensin. International Energy Agency (IEA) melaporkan bahwa penggunaan biofuel diproyeksikan dapat mengurangi emisi $\mathrm{CO}_{2}$ sekitar 2,1 giga ton per tahun 2050 jika diproduksi secara stabil (Jin dan Sutherland, 2016).

Bioetanol merupakan bioenergi yang dapat diperbarui, dan sedikit polusi. Bioetanol dapat diolah dari berbagai jenis tanaman berpati (ubikayu, jagung, sorgum biji, sagu), tanaman bergula (tebu, sorgum manis, bit) serta selulosa (jerami, serbuk kayu sisa pengger gajian kayu, ampas tahu, kulit biji kacang kedelai). Terdapat beberapa bahan dapat diolah menjadi bioetanol, salah satunya adalah lignoselulosa. Lignoselulosa merupakan biomassa yang berasal dari tanaman dengan komponen utama lignin, selulosa, dan hemiselulosa (Hermiati et al. 2010). Lignoselulosa dapat diperoleh dari limbah pengolahan hasil pertanian, limbah pengolahan kayu, dan limbah padat organik (Maeda, et al. 2013). Lignoselulosa menjadi bahan baku yang sangat menjanjikan karena tidak diperlukan lahan tambahan untuk memproduksi bahan baku dan tidak mengganggu persediaan bahan pangan maupun pakan (Boycea et al. 2017).

Indonesia merupakan negara penghasil ubi kayu terbesar ketiga $(23,4$ juta ton) setelah Nigeria (54,8 juta ton) Thailand (30,0 juta ton) dari total produksi dunia sebesar 270,3 juta ton per tahun. Berdasarkan kontribusi terhadap produksi nasional terdapat sepuluh propinsi utama penghasil ubi kayu yaitu Lampung, Jawa Tengah, Jawa Timur, Jawa Barat, Sulawesi Utara, DI Yogyakarta, NTT, Sulawesi Selatan menyumbang 91,21\% dari produksi nasional (Pusat Data dan Sistem Informasi Pertanian, 2016). Pada proses pengolahan ubi kayu menjadi tapioka, dihasilkan limbah sekitar dua per tiga bagian atau sekitar 75\% dari bahan mentah. Data BPS tahun 2015 menunjukkan produksi ubi kayu Indonesia 21,8 juta ton. Dari jumlah tersebut diperkirakan dihasilkan 2,5 juta ton onggok, dan jika dikonversi akan diperoleh sekitar 181 ribu kilo liter bioetanol (Nisa, 2014). 
Limbah usaha kecil pangan seperti industri tahu, tempe, tapioka dan industri pangan lainnya juga dapat menimbulkan masalah dalam penanganannya karena mengandung sejumlah besar karbohidrat, protein, lemak , garam-garam, mineral, dan sisa sisa bahan kimia yang digunakan dalam pengolahan dan pembersihan (Habibi dan Marwan, 2018).

Berdasarkan potensi yang terdapat pada limbah padat industri tepioka dan tahu, pemanfaatan kedua jenis limbah padatnya berpotensi sebagai bahan baku pembuatan bioetanol.

Salah satu tahapan dalam produksi bioetanol dari bahan baku selulosa adalah proses hidrolisis. Proses hidrolisis dengan asam dapat dikelompokkan menjadi hidrolisis asam pekat dan hidrolisis asam encer (Taherzadeh dan Karimi, 2007). Hidrolisis asam pekat merupakan teknik yang sudah dikembangkan cukup lama dimana Bracannot tahun 1819 merupakan orang pertama menemukan bahwa selulosa bisa dikonversi menjadi gula yang dapat difermentasi, dengan menggunakan asam pekat (Sherrad dan Kressman, 1945 dalam Taherzadeh dan Karimi, 2007). Hidrolisis dengan asam pekat menghasilkan gula yang tinggi ( $90 \%$ dari hasil teoritik) dibandingkan dengan asam encer (Hamelinck et al., 2005). Hidrolisis asam dapat dilakukan pada suhu rendah, namun dengan konsentrasi asam yang tinggi (30-70\%). Proses hidrolisis dengan asam kuat sangat korosif, sehingga membutuhkan peralatan yang dibuat secara khusus yang biasanya terbuat dari bahan metal dengan spesifikasi terrtentu sehingga harganya mahal. Pengambilan kembali asam (recovery) juga membutuhkan energi yang besar. Selain itu jika menggunakan asam sulfat, dibutuhkan proses netralisasi yang menghasilkan limbah kapur (gypsum) yang sangat banyak. Proses tersebut memberikan pengaruh yang kurang baik bagi lingkungan. Pada akhirnya hidrolisis asam pekat membutuhkan biaya investasi dan pemeliharaan yang tinggi, dan hal tersebut mengurangi ketertarikan untuk komersialisasi (Taherzadeh dan Karimi, 2007).

Pada hidrolisis dengan asam encer merupakan metode hidrolisis yang banyak dikembangkan dan diteliti saat ini, dikenal juga dengan hidrolisis asam dua tahap (two stage acid hydrolysis). Hidrolisis asam encer pertama kali dipatenkan oleh H.K. Moore pada tahun 1919, dimana potongan (chip) kayu dimasukkan ke dalam tangki kemudian diberi uap panas pada suhu $300^{\circ} \mathrm{F}$ selama satu jam. Selanjutnya dihidrolisis dengan menggunakan asam fosfat. Hidrolisis dilakukan dalam dua tahap. Hidrolisis yang dihasilkan kemudian difermentasi untuk menghasilkan etanol. Hidrolisis selulosa dengan menggunaka asam telah dikomersialisasikan pertama kali pada tahun 1898 (Hamelinck et al., 2005). Tahap pertama dilakukan dalam kondisi yang lebih "lunak" (seperti 0,7\% asam sulfat, $190^{\circ} \mathrm{C}$ ) dan akan menghidrolisis hemiselulosa. Tahap kedua dilakukan pada suhu yang lebih tinggi, tetapi dengan konsentrasi asam yang lebih rendah (seperti $0,4 \%$ asam sulfat suhu $215^{\circ} \mathrm{C}$ (Hamelinck et al. 2005).

Penelitian ini bertujuan memanfaatkan limbah padat industri tepung tapioka (ampas ubi kayu/onggok) dan industri tahu (ampas tahu) sebagai bahan baku pembuatan bioetanol, menentukan konsentrasi $\mathrm{H}_{2} \mathrm{SO}_{4}$ pada proses hidrolisis berdasarkan konsentrasi glukosa tertinggi, dan menentukan kadar etanol yang dihasilkan melalui proses fermentasi.

\section{METODE PENELITIAN}

Bahan-bahan yang digunakan adalah limbah padat/onggok dari industri tepung tapioka dan industri tahu, ragi instan (merk Instant Succes), $\mathrm{H}_{2} \mathrm{SO}_{4}$, reagent DNS, $\mathrm{CaOH}_{2}$ dan bahan kimia lain.

Alat-alat yang digunakan adalah neraca analitik, pH meter, shaker incubator, autoklaf, spektofotometer UV Vis, oven, dan alat analisa lainnya.

Pada penelitian ini, proses pembuatan bioetanol dilakukan dalam beberapa tahap dan menggunakan sumber bahan baku yang berbeda. Metode yang digunakan pada penelitian ini adalah metode hidrolisis asam diteruskan dengan fermentasi. Pada penelitian ini dilakukan uji coba beberapa perlakuan sumber onggok, konsentrasi ragi dan lama fermentasi. Perlakuannya

\section{Nanti Musita}

Pemanfaatan Limbah Padat Industri Tepung Tapioka dan Industri Tahu Sebagai

Bahan Baku Bioetanol dengan Proses Hidrolisa $\mathrm{H}_{2} \mathrm{SO}_{4}$ dan Fermentasi Ragi Instan 
adalah 2 jenis sumber onggok yaitu dari industri tahu (A) dan industri tapioka (B) 5 taraf untuk konsentrasi $\mathrm{H}_{2} \mathrm{SO}_{4}$ yaitu $0,1 \mathrm{M}, 0,2 \mathrm{M}, 0,3 \mathrm{M}, 0,4 \mathrm{M}$, dan $0,5 \mathrm{M}$. Dan pada proses fermentasi dilakukan pengamatan pada hari ke 0 , hari ke 1 , hari ke 3 dan hari ke 5 .

\section{Pelaksanaan Penelitian}

1. Pembuatan Tepung Onggok

Pengeringan dan penggilingan onggok untuk mendapatkan tepung onggok. Tepung onggok kemudian dianalisa, kadar air, abu, pati, serat kasar, protein, dan lemak.

2. Proses Hidrolisa Asam.

Hidrolisa tepung onggok dengan larutan $\mathrm{H}_{2} \mathrm{SO}_{4}$ konsentrasi $0,1 \mathrm{M}, 0,2 \mathrm{M}, 0,3 \mathrm{M}, 0,4 \mathrm{M}$, dan $0,5 \mathrm{M}$, menggunakan autoklafe pada suhu $121^{\circ} \mathrm{C}$ selama 30 menit tekanan $1 \mathrm{~atm}$. Hasil hidrolisa disaring. Filtrat hasil saringan dianalisa $\mathrm{pH}$ dan kadar glukosanya.

3. Fermentasi etanol.

Filtrat tersebut kemudian dinetralkan dengan $\mathrm{Ca}(\mathrm{OH})_{2}$ sampai $\mathrm{pH}$ mencapai 5-6, kemudian ditambahkan urea dan NPK 1\%, $\left(\mathrm{NH}_{4}\right)_{2} \mathrm{HPO}_{4} 0,1 \%$, ragi instant $5 \%$. Kemudian ditutup rapat dengan sumbat kapas dan ditempatkan dalam alat shaker incubator selama 1-5 hari pada suhu $30^{\circ} \mathrm{C}$ kecepatan $150 \mathrm{rpm}$. Selama fermentasi dilakukan pengamatan terhadap $\mathrm{pH}$, kadar etanol, dan kadar glukosa.

4. Pengamatan

Pengamatan terhadap tepung onggok meliputi kadar air, abu, protein, lemak, pati, dan serat kasar. Pengamatan pada hasil fermentasi meliputi pH, etanol dan glukosa. Kemudian data disajikan secara deskriptif dalam bentuk Tabel.

\section{HASIL DAN PEMBAHASAN}

\section{Kadar Proksimat Tepung Onggok}

Tepung onggok yang dipergunakan pada penelitian ini berasal dari onggok basah yang dikeringkan selama 2-3 hari, digiling kemudian di ayak, sehingga diperoleh tepung yang halus (Gambar 1).

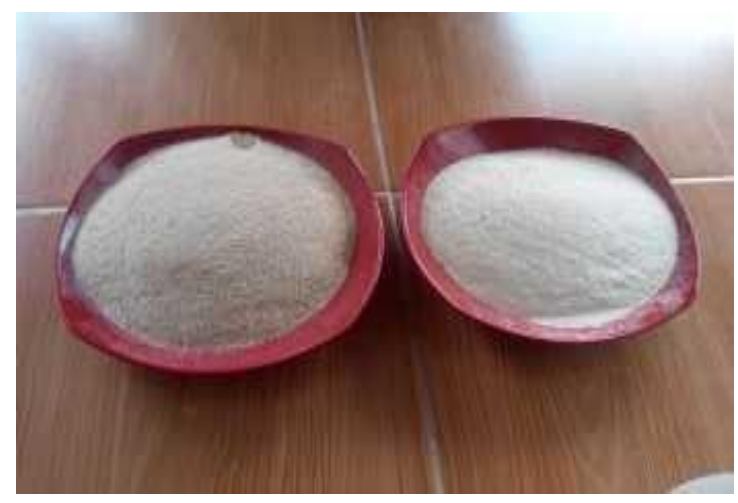

Gambar 1. Tepung onggok industri tepung tapioka (kiri) dan industri tahu (kanan)

Gambar 1 memperlihatkan bentuk tepung onggok yang dihasilkan. Tepung onggok dari industri tapioka lebih gelap (agak coklat) dibandingkan tepung onggok dari industri tahu. Perbedaan ini disebabkan perbedaan bahan baku dan proses yang dilakukan untuk memperoleh tepung onggok tersebut. 
Tabel 1. Kadar proksimat tepung onggok

\begin{tabular}{lcc}
\hline Parameter & Industri Tahu (A) & Industri Tapioka (B) \\
\hline Kadar air (\%) & 4,37 & 6,86 \\
Kadar abu (\%) & 3,85 & 1,95 \\
Kadar protein (\%) & 21,56 & 1,42 \\
Kadar lemak (\%) & 8,73 & 0,17 \\
Kadar pati (\%) & 24,54 & 40,84 \\
Kadar serat kasar (\%) & 17,82 & 23,93 \\
\hline
\end{tabular}

Tabel 1 menunjukkan bahwa kadar proksimat tepung onggok industri tahu berbeda dengan tepung onggok industri tapioka. Onggok dari industri tahu mengandung kadar abu, lemak dan protein lebih besar dan onggok dari industri tapioka mempunyai kadar air, pati dan serat kasar yang lebih besar. Kondisi ini disebabkan perbedaan sumber bahan baku dan proses produksi di antar keduanya. Namun keduanya masih memiliki sumber karbohidrat (pati dan serat kasar) yang cukup besar (lebih dari 40\%) yang dapat dijadikan bahan baku untuk pembuatan bioetanol. Menurut Suprapti (2005), ampas tahu kering mempunyai protein kasar 23,39\%, lemak kasar 9,96\%, serat kasar 19,44\%, abu 4,58 \%.

Pada onggok ubi kayu perlu proses sakarifikasi, dapat dilakukan dengan proses hidrolisis secara enzim ataupun asam. Menurut Susmiati (2018), bahan yang kandungan utamanya adalah selulosa, hemiselulosa dan lignin (kulit pisang, kulit kentang, jerami, bagas, tandan kosong kelapa sawit) maka perlu proses sakarifikasi yang harus didahului dengan proses pretreatment.

\section{Proses Hidrolisa Asam}

Proses fermentasi didahului dengan proses hidrolisa asam selama 30 menit pada suhu $121^{\circ} \mathrm{C}$ tekanan $1 \mathrm{~atm}$ dengan autoklaf. Pada penelitian ini menggunakan $\mathrm{H}_{2} \mathrm{SO}_{4}$ dengan konsentrasi $0,1 \mathrm{M}, 0,2 \mathrm{M}, 0,3 \mathrm{M}, 0,4 \mathrm{M}$, dan 0,5 M. Hasil hidrolisa kemudian diamati pH, kadar gula reduksi $(\mathrm{mg} / \mathrm{ml})$ seperti tertera pada Gambar 2 dan 3.

Proses Hidrolisis terhadap onggok tahu dan tapioka menggunakan $\mathrm{H}_{2} \mathrm{SO}_{4}$ merupakan perlakuan awal (pretreatment) sekaligus proses hidrolisa. Menurut Hafid et al (2017), perlakuan awal (pretreatment) perlu dilakukan dalam proses pembuatan bioetanol dari biomassa berupa limbah pertanian ataupun sampah organik. Proses pretreatment dilakukan untuk mengkondisikan bahan-bahan lignosellulosa baik dari segi struktur dan ukuran. Proses perlakuan awal dilakukan karena beberapa faktor seperti kandungan lignin, ukuran partikel serta kemampuan hidrolisis dari selulosa dan hemiselulosa (Hendriks dan Zeeman, 2009). Pretreatment bertujuan untuk mengubah atau merusak struktur dari komponen penyusun pada biomassa tersebut sehingga memudahkan enzim untuk menghidrolisis menjadi monomer-monomer gula (Hafid et al., 2017). Proses ini mengacu pada proses pelarutan dan pemisahan satu atau lebih komponen-komponen dari bahan (biomassa) sehingga pada ikatan komponen bahan tersebut menjadi longgar dan memudahkan bahan kimia ataupun biologi masuk kemudian menguraikannya (Sumada et al., 2011). Pada penelitian tentang delignifikasi dengan $\mathrm{H}_{2} \mathrm{SO}_{4} 0,5 \%$ suhu $121^{\circ} \mathrm{C}$ selama 30 menit pada ampas tebu diketahui , terjadi penurunan kadar lignin dari 21,11\% menjadi 12,97\% (Wardani dan Kusumawardini, 2012). Dan pada delignifikasi ampas tebu menggunakan $\mathrm{NaOH}$ menunjukkan pengurangan lignin terbanyak diperoleh melalui penggunaan $\mathrm{NaOH} 6 \%$ yaitu sebesar $32 \%$, dari $17,65 \%$ menjadi 11,9\% (Gunam et al., 2011). 


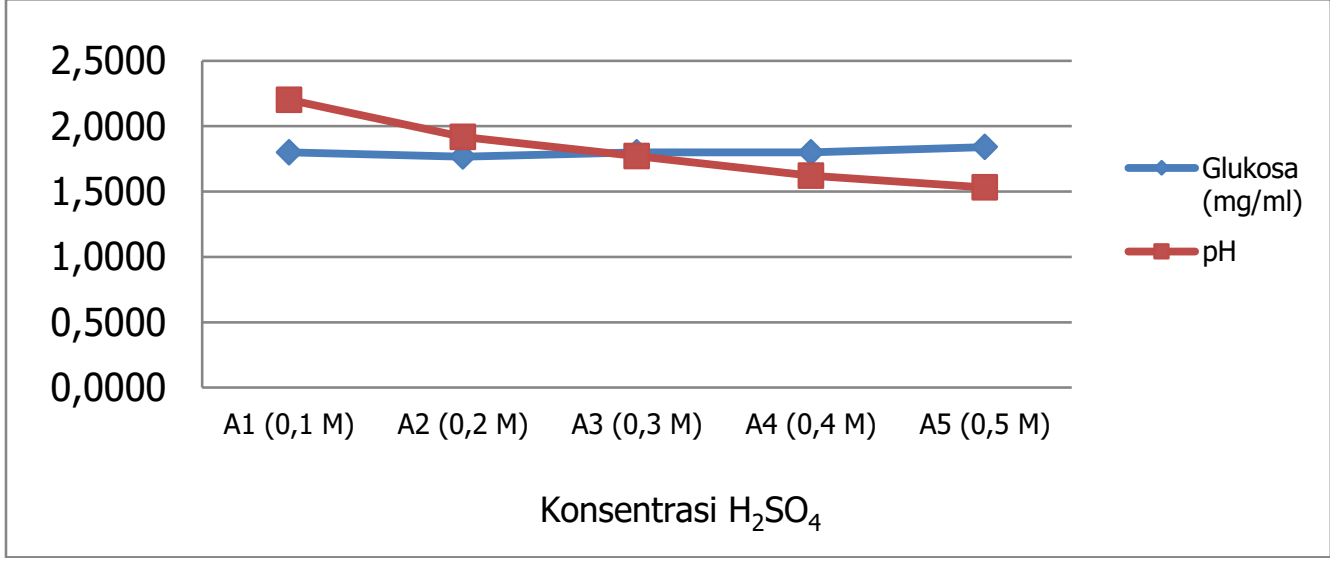

Gambar 2. Hasil analisa onggok tahu setelah proses hidrolisa dengan berbagai konsentrasi $\mathrm{H}_{2} \mathrm{SO}_{4}$

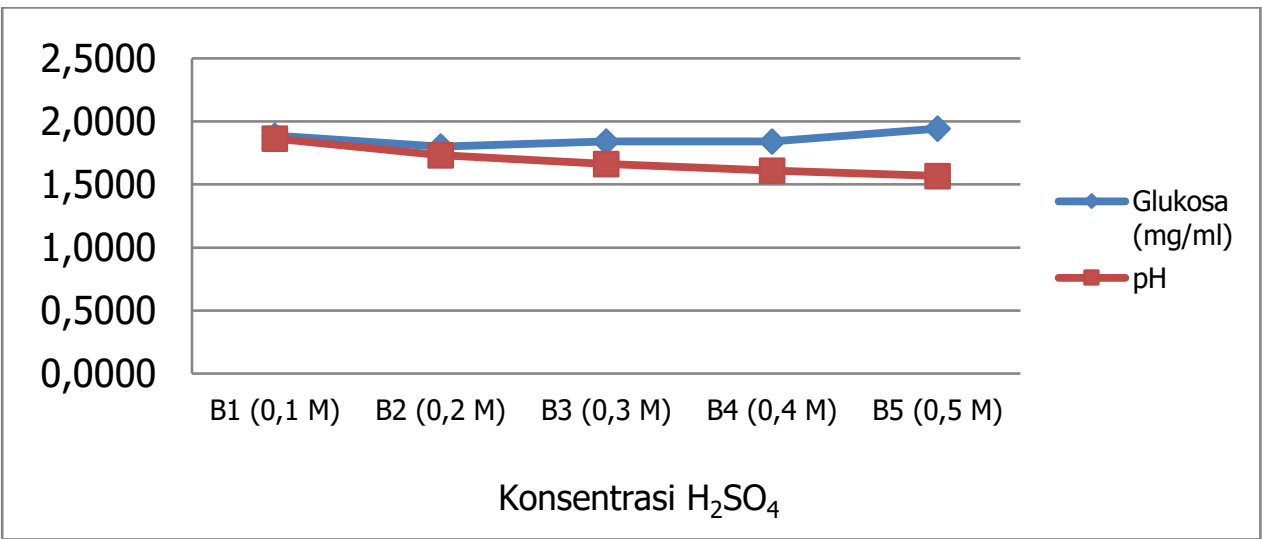

Gambar 3. Hasil analisa onggok tapioka setelah proses hidrolisa dengan berbagai konsentrasi $\mathrm{H}_{2} \mathrm{SO}_{4}$

Gambar 2 dan 3 menunjukkan kadar glukosa dan pH onggok tahu dan tapioka pada konsentrasi $\mathrm{H}_{2} \mathrm{SO}_{4}$ yang berbeda. Kadar glukosa onggok tapioka lebih tinggi dibandingkan onggok tahu. Pada keseluruhan proses hidrolisa kadar glukosa tertinggi yaitu $1,9431 \mathrm{mg} / \mathrm{ml}$ (tapioka) dan $1,8398 \mathrm{mg} / \mathrm{ml}$ (tahu)yang berasal dari penggunaan $\mathrm{H}_{2} \mathrm{SO}_{4}$ sebesar $0,5 \mathrm{M}$. Penggunaan $\mathrm{H}_{2} \mathrm{SO}_{4}$ 0,5 $\mathrm{M}$ menghasilkan glukosa paling tinggi dibandingkan konsentrasi lainnya. Jumlah $\mathrm{H}_{2} \mathrm{O}$ dalam larutan $\mathrm{H}_{2} \mathrm{SO}_{4} 0,1 \mathrm{M}-0,4 \mathrm{M}$ lebih banyak dari konsentrasi 0,5 M sehingga berpengaruh terhadap viskositas larutan yang dihidrolisis. Semakin besar viskositas larutan, tumbukan antar reaktan menjadi berkurang sehingga reaksi berjalan lebih lambat. Hal ini disebabkan $\mathrm{H}_{2} \mathrm{SO}_{4}$ berfungsi sebagai katalis, sehingga semakin besar konsentrasi katalis maka semakin cepat pula reaksi berlangsung yang akan menghasilkan kadar glukosa. Keberadaan katalis dalam suatu reaksi akan meningkatkan laju reaksi. Namun katalis tidak ikut bereaksi dan tidak mengalami perubahan secara kimiawi pada akhir reaksi. Katalisator juga berfungsi untuk menurunkan energi aktivasi. Jika jumlah katalisator dinaikkan, maka energi aktivasi akan turun, sehingga laju reaksi akan meningkat (Setyaningsih et al., 2017).

Penelitian Hikmiyati dan Yani (2009) menunjukkan glukosa tertinggi 28,31 g/L dari hidrolisa dengan $0,3 \mathrm{M} \mathrm{H}_{2} \mathrm{SO}_{4}$ pada kulit singkong. Pada penelitian lain, penggunaan enzim pada hidrolisa onggok yaitu menggunakan Enzim Glukoamilase 0,6 unit/gram dihasilkan glukosa sebesar 115,859 g/L untuk waktu 24 jam, dan Enzim Pektinase 15 unit/gram dihasilkan glukosa sebesar 29,4 g/L untuk waktu 2 jam (Rahmasari dan Putri, 2012). 


\section{Fermentasi Etanol}

Proses fermentasi onggok 1 - 5 hari menggunakan ragi instant sebagai sumber mikrobanya. Pengamatan dilakukan pada kadar etanol, pH, dan glukosa (Gambar 4 - 9).

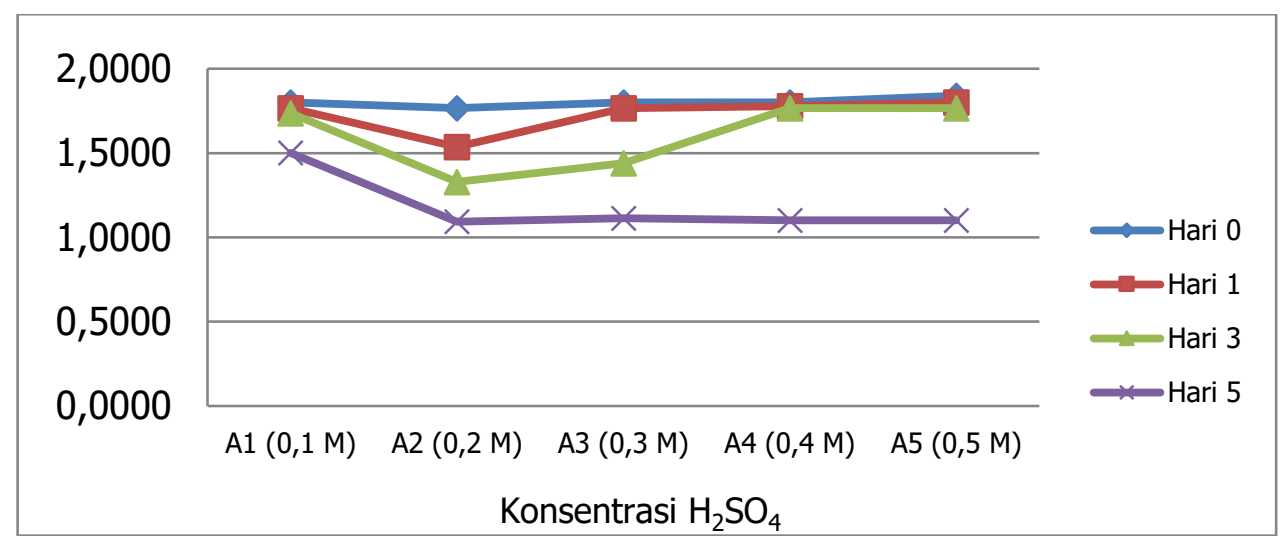

Gambar 4. Kadar glukosa (mg/ml) hasil proses fermentasi onggok tahu pada berbagai konsentrasi $\mathrm{H}_{2} \mathrm{SO}_{4}$

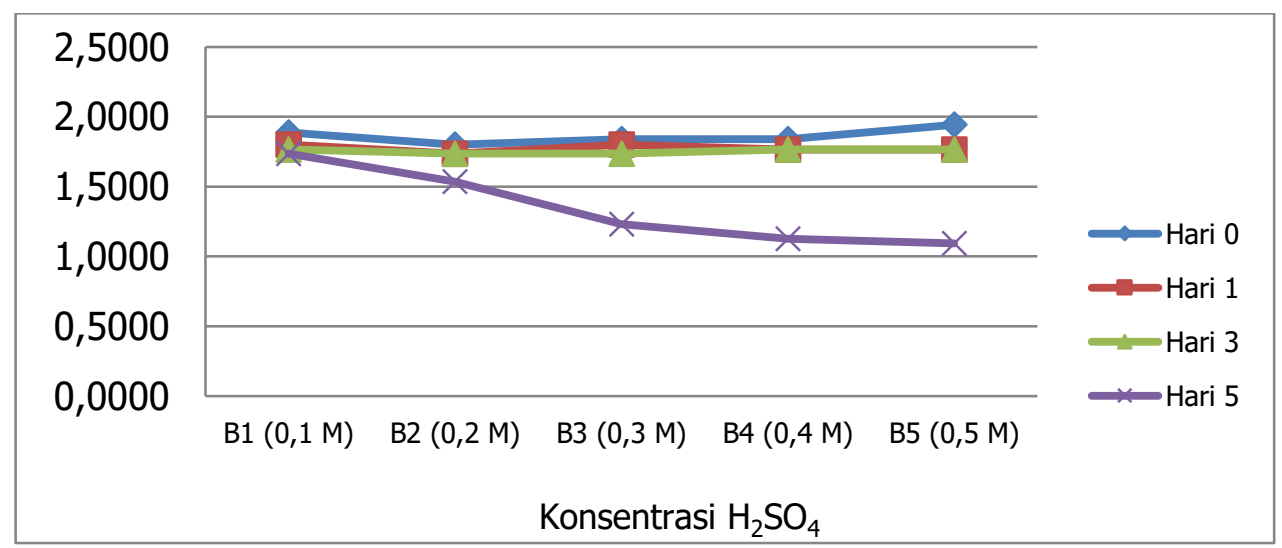

Gambar 5. Kadar glukosa $(\mathrm{mg} / \mathrm{ml})$ hasil proses fermentasi onggok tapioka pada berbagai konsentrasi $\mathrm{H}_{2} \mathrm{SO}_{4}$

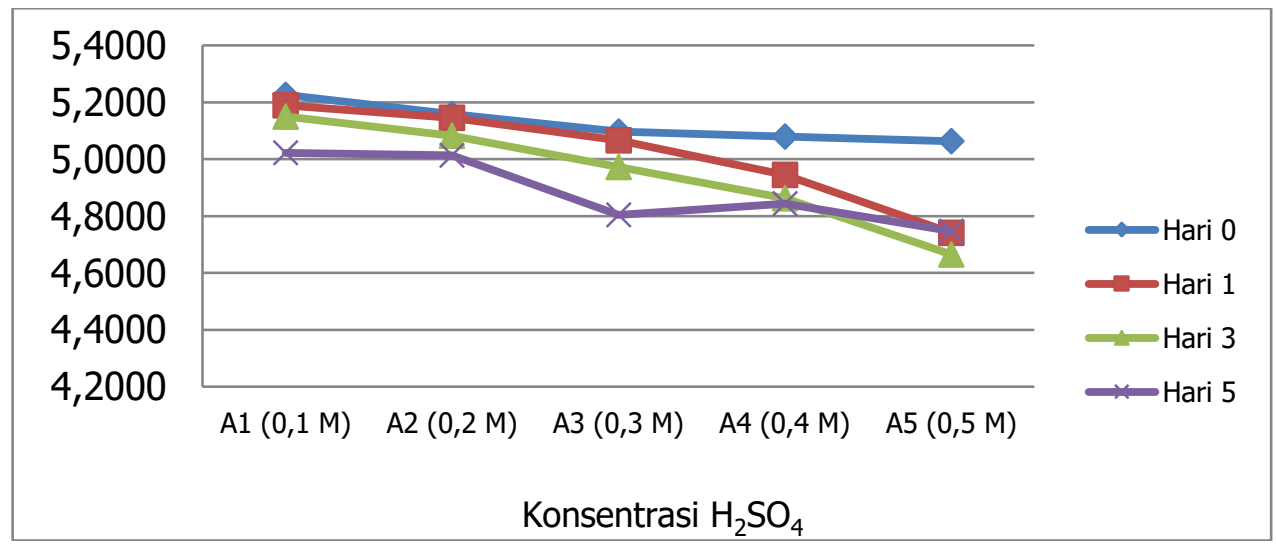

Gambar 6. Tingkat keasaman $(\mathrm{mg} / \mathrm{ml})$ hasil proses fermentasi onggok tahu pada berbagai konsentrasi $\mathrm{H}_{2} \mathrm{SO}_{4}$ 


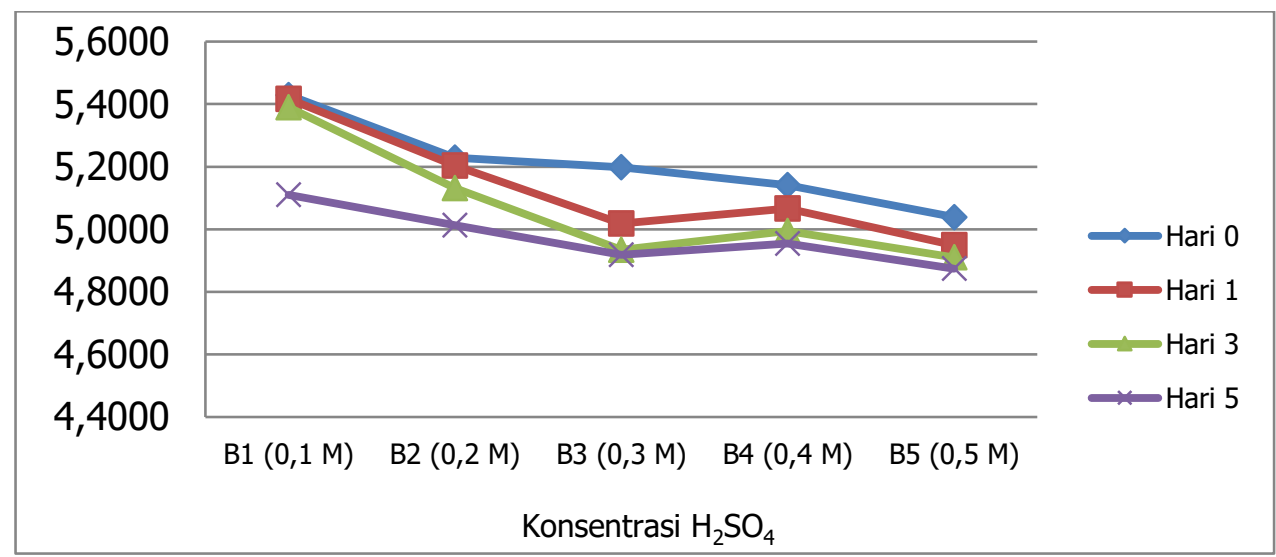

Gambar 7. Tingkat keasaman $(\mathrm{mg} / \mathrm{ml})$ hasil proses fermentasi onggok tapioka pada berbagai konsentrasi $\mathrm{H}_{2} \mathrm{SO}_{4}$

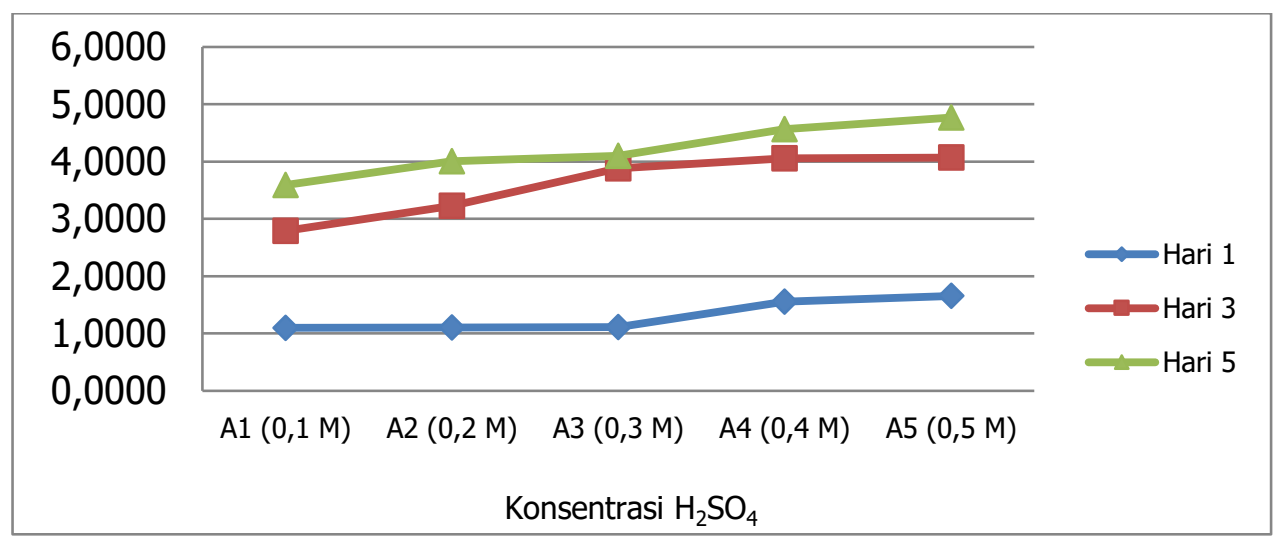

Gambar 8. Kadar etanol (\%) hasil proses fermentasi onggok tahu pada berbagai konsentrasi $\mathrm{H} 2 \mathrm{SO} 4$

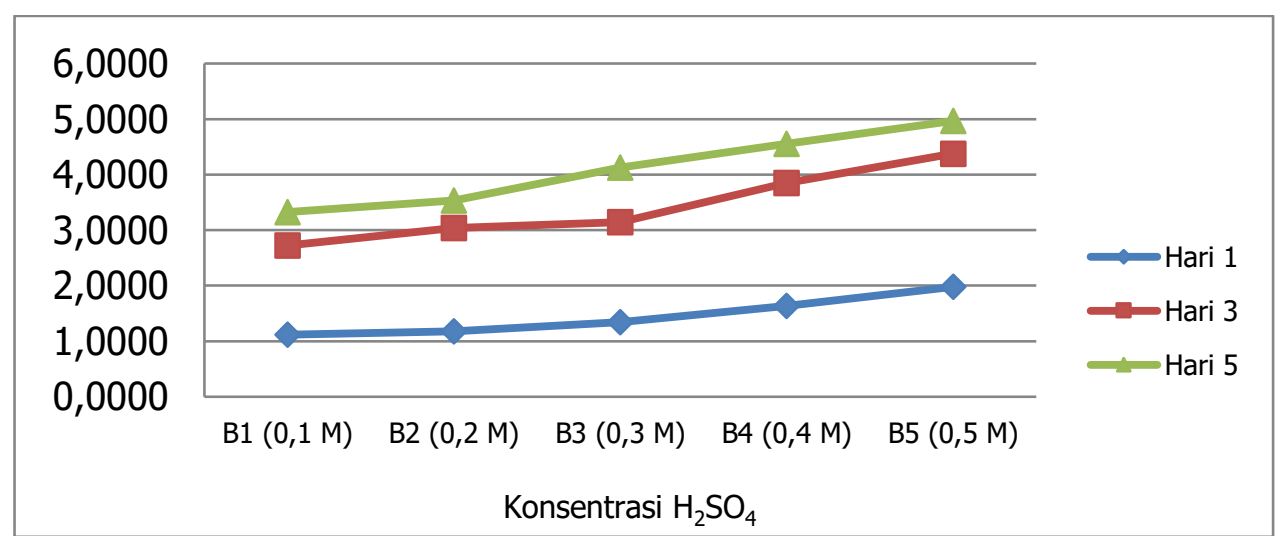

Gambar 9. Kadar etanol (\%) hasil proses fermentasi onggok tapioka pada berbagai konsentrasi $\mathrm{H}_{2} \mathrm{SO}_{4}$

Gambar 4 - 7 menunjukkan perubahan kadar glukosa dan tingkat keasaman onggok yang semakin berkurang dengan bertambahnya konsentrasi $\mathrm{H}_{2} \mathrm{SO}_{4}$ dan lama fermentasi. Bentuk perubahan tersebut berbanding terbalik dengan perubahan kadar etanol hasil fermentasi onggok (Gambar 8 - 9).

Gambar 4 - 9 juga menunjukkan perbedaan kadar glukosa, etanol, dan pH karena perbedaan sumber onggok. Fermentasi onggok dari tapioka menghasilkan sisa glukosa yang lebih tinggi dibandingkan onggok tahu. Dalam proses pembuatan bioetanol dari limbah 
pertanian ada beberapa faktor yang berpengaruh untuk mendapatkan etanol yang optimal antara lain suhu, pH, waktu inkubasi, konsentrasi substrat, beban mikroba dan akumulasi by product (Zabed et al., 2017).

Gambar 4 - 5 menunjukkan perubahan kadar glukosa selama fermentasi, yaitu terjadi penurunan sejak hari pertama fermentasi dan pada hari ke tiga penurunan glukosa semakin besar. Sisa gula terfermentasi cenderung makin sedikit dengan semakin lamanya proses fermentasi. Semakin rendah konsentrasi gula pada substrat awal, makin rendah pula jumlah sisa gula didalam setiap volumenya.

Gambar 6 - 7 menunjukkan perubahan pH media selama proses fermentasi, baik pada onggok yang berasal dari tahu juga tapioka. Penurunan $\mathrm{pH}$ secara nyata nampak setelah hari ketiga fermentasi.

Tingkat keasaman atau $\mathrm{pH}$ medium merupakan salah satu faktor penting yang mempengaruhi pertumbuhan mikroorganisme dan pembentukan produk dalam proses fermentasi karena setiap mikroorganisme mempunyai kisaran $\mathrm{pH}$ optimal. Dalam proses fermentasi terjadi penurunan. Perubahan $\mathrm{pH}$ dalam fermentasi disebabkan karena dalam aktivitasnya sel khamir selain menghasilkan etanol sebagai metabolit primer juga menghasilkan asam-asam organik seperti asam malat, asam tartarat, asam sitrat, asam laktat, asam asetat, asam butirat dan asam propionate sebagai hasil sampingan. Asam-asam ini menurunkan $\mathrm{pH}$ medium (Sugiharto, 1991).

$\mathrm{pH}$ pada proses hidrolisis dan fermentasi menjadi penting karena enzim atau mikroba akan dapat hidup optimal pada $\mathrm{pH}$ tertentu, seperti enzim selulase pada $\mathrm{pH}$ 4,5-5, Saccharomyces cerevisiae memiliki daya konversi gula menjadi etanol yang sangat tinggi, sehingga sering digunakan dalam fermentasi alkohol. Saccharomyces cereviseae memerlukan suhu $30^{\circ} \mathrm{C}$ dan $\mathrm{pH}$ 4,0 - 5,5 agar dapat tumbuh dengan baik (Sassner et al., 2008). Saccharomyces cerevisiae dapat menghasilkan etanol dengan optimal pada $\mathrm{pH} 4-5$ dan Zimomonas mobilis optimal pada pH 5 - 6 (Zabed et al., 2017).

Berdasarkan Gambar 8 - 9, pada saat hari kelima fermentasi menunjukkan konsentrasi etanol tertinggi untuk semua perlakuan konsentrasi $\mathrm{H}_{2} \mathrm{SO}_{4}$ baik pada onggok tapioka maupun onggok tahu. Hal ini diduga karena ketersediaaan nutrisi pada medium masih cukup besar. Konsentrasi substrat yang tinggi akan mempengaruhi pertumbuhan mikroba fermentasi. Konsentrasi substrat pada waktu proses berkisar antara 12\%-8\%. Semakin tinggi konsentrasi substrat dibutuhkan waktu yang semakin lama, karena gula yang ada meningkatkan pertumbuhan mikroba untuk pembentukan sel dan memperlama proses penghasilan etanol, sehingga meningkatkan biaya recovery selanjutnya (Zabed et al., 2017). Hasil penelitian Hikmiyati dan Yani (2008) menunjukkan waktu fermentasi optimum dicapai pada saat 96 jam dengan kadar etanol 1,95 \% v/v dan densitas sebesar 1,052 gr/mL dengan bahan baku kulit singkong. Sedangkan untuk ampas sagu memerluka asam sulfat dengan konsentrasi 0,3 N selama 120 menit dan memberikan konsetrasi gula reduksi sebesar 4,477 g/L. Selama fermentasi berlangsung terjadi penurunan $\mathrm{pH}$ medium dan peningkatan jumlah sel. Produksi Etanol optimum terjadi pada lama fermentasi 4 hari dengan konsentrasi etanol 7,69\% (Idral et al., 2012).

Fermentasi alkohol atau alkoholisasi adalah proses perubahan gula menjadi alkohol dan $\mathrm{CO}_{2}$ oleh mikroba, terutama oleh khamir Saccharomyces cerevisiae. Karbohidrat akan dipecah dahulu menjadi gula sederhana yaitu hidrolisis pati menjadi unit-unit glukosa. Selanjutnya gula terfermentasi oleh Saccharomyces cerevisiae akan diubah menjadi alkohol dan gas $\mathrm{CO}_{2}$ sebagian lagi akan berubah menjadi massa khamir. Apabila diperhatikan maka antara jumlah gula terfermentasi dengan produksi alkohol berbanding lurus.

Dalam tahap pertama fermentasi glukosa selalu terbentuk asam piruvat melalui jalur Embden Meyerhof Parnas (EMP) atau glikolisis. Piruvat tersebut diubah menjadi alkohol melalui dua tahap yaitu pertama, piruvat didekarboksilasi menjadi asetaldehid oleh piruvat

\section{Nanti Musita}

Pemanfaatan Limbah Padat Industri Tepung Tapioka dan Industri Tahu Sebagai

Bahan Baku Bioetanol dengan Proses Hidrolisa $\mathrm{H}_{2} \mathrm{SO}_{4}$ dan Fermentasi Ragi Instan 
dekarboksilase dengan melibatkan tiamin pirofosfat dan tahap kedua asetaldehid oleh alcohol dehidrogenase direduksi dengan $\mathrm{NADH}_{2}$ menjadi alkohol (Idral et al., 2012).

Selama proses fermentasi tidak menutup kemungkinan terjadi pertumbuhan bakteri kontaminan dan terbentuk produk samping seperti asam laktat, asam asetat dan gliserol sebagai hasil dari aktivitas metabolik pada yeast dan bakteri kontaminan tersebut. Sehingga waktu fermentasi juga berpengaruh. Menurut Zabed et al. (2017), waktu inkubasi merupakan faktor yang berpengaruh secara signifikan pada proses hidrolisis dan fermentasi. Waktu hidrolisis secara enzimatis lebih lama dibandingkan hidrolisis secara kimia (asam). Waktu fermentasi yang optimal 42-72 jam, akan tetapi sampai 96 jam mikroba masih menghasilkan etanol. Proses fermentasi yang terlalu lama akan mengakibatkan keracunan proses yang dapat membunuh mikroba.

\section{KESIMPULAN}

Onggok tapioka dan onggok tahu dapat dimanfaatkan sebagai bahan baku pembuatan bioetanol. Konsentrasi $\mathrm{H}_{2} \mathrm{SO}_{4}$ yang optimum untuk menghidrolisa onggok tahu dan tapioka pada konsentrasi $0,5 \mathrm{M}$ selama 30 menit suhu $121^{\circ} \mathrm{C}$. Selama fermentasi berlangsung terjadi penurunan $\mathrm{pH}$ dan glukosa serta peningkatan produksi etanol. Produksi etanol optimum terjadi pada lama fermentasi 5 hari dengan konsentrasi etanol 4,77\% b/b dari onggok tahu dan $4,97 \% \mathrm{~b} / \mathrm{b}$ dari onggok tapioka.

\section{DAFTAR PUSTAKA}

Badan Pusat Statistik. Statistik Lingkungan Hidup Indonesia 2016. Badan Pusat Statistik; 2016. Boycea AN , Faruq G, Sahuc JN, Suelya A, Zabeda H. 2017. Bioethanol Production from Renewable Sources: Current Perspectives And Technological Progress. Renewable And Sustainable Energy Reviews. 2017; 475-501.

Dinas Peternakan Kandungan Ampas Tahu. Dinas Peternakan Provinsi Jawa Timur; . 2011.

Dirjen Minyak dan Gas. Neraca gas Bumi Indonesia 2018-2027. Kementerian ESDM RI. Jakarta. 70 halaman; 2018.

Gunam, IB, Wartini NM, Anggreni AA, Suparyana PM. Delignifikasi Ampas Tebu Dengan Larutan Natrium Hidroksida Sebelum Sakarifikasi Secara Enzimatis Menggunakan Enzim Selulase Kasar Dari Aspergillus Niger FNU 6018. Teknologi Indonesia LIPI Press 34 (Edisi Khusus 2011): 24--32.

Habibi F, Marwan R. Pengaruh Limbah terhadap Lingkungan dan Penyakit Yang Timbul serta Penaggulangannya. Proseding Seminar dan Konferensi Nasional IDEC; 2018.

Hafid HS, Rahman NAA, Shah UKM, Baharuddin AS, Ariff AB. Feasibility of Using Kitchen Waste as Future Substrate for Bioethanol Production: A review. Renewable and Sustainable Energy Reviews. 2017; 74:671-686.

Hamelinck CN, Hooijdonk V, Faaij APC. Ethanol from Lignocellulosic Biomass: TechnoEconomic Performance in Short, Middle and Long-Term. Biomass and Bioenergy. 2005; 28:384-410.

Hendriks AT, Zeeman G. Pretreatments to Enhance The Digestibility of Lignocellulosic Biomass. Bioresource Technology. 2009; 100:10-18.

Hermiati E, Mangunwidjaja D, Sunarti TC, Suparno O, Prasetya B. Pemanfaatan Biomassa Lignoselulosa Ampas Tebu untuk Produksi Bioetanol. Jurnal Litbang Pertanian. 2010; 122-130.

Hikmiyati N, Yani NS. Pembuatan Bioetanol dari Limbah Kulit Singkong Melalui Proses Hidrolisa Asam dan Enzimatis. Tugas Akhir Fakultas Teknik Universitas Diponegoro. Semarang. 2009

Idral DD, Salim M, Mardiah E. 2012. Pembuatan Bioetanol dari Ampas Sagu dengan Proses Hidrolisis Asam dan Menggunakan Saccharomyces cerevisiae. Jurnal Kimia Unand. 2012; 
1(1).

Jin E, Sutherland JW. A Proposed Integrated Sustainability Model for a Bioenergy System. Procedia CIRP. 2016; 48:358-363.

Maeda R, Nobuyuki, Barcelos CA, Anna LMMS, Pereira N Jr. Cellulase Production by Penicillium Funiculosum and Its Application in The Hydrolysis of Sugar Cane Bagasse for Second Generation Ethanol. Journal of Biotechnology. 2013; 38-44.

Nisa, WW. Produksi Bioetanol dari Onggok (Limbah Padat Tapioka) dengan Proses Sakarifikasi dan Fermentasi Serentak Menggunakan Khamir Hasil Isolasi dari Tetes Tebu. Skripsi. Jurusan Kimia Fakultas Sains danTeknologi. Universitas Islam Negeri Maulana Malik Ibrahim. Malang dalam Susmiati, Y. 2018. Prospek Produksi Bioetanol dari Limbah Pertanian dan Sampah Organik. Industria. Jurnal Teknologi dan Manajemen. 2014; 7(2): 67-80.

Pusat Data dan Sistem Informasi Pertanian. Outlook Komoditas Pertanian Tanaman Pangan Ubi Kayu. epublikasi. setjen.pertanian.go.id/.../Outlook\%20Ubikayu\%202015/..... Kementerian Pertanian RI, Jakarta. 2016.

Rahayu ES, Rahayu S, Sidar A, Purwadi T, Rochdyanto S. Teknologi Proses Produksi Tahu. Kanisius, Yogyakarta. 2012.

Rahmasari S, Putri KP. Pengaruh Hidrolisis Enzim pada Produksi Ethanol dari Limbah Padat Tepung Tapioka (Onggok). Skripsi. Institut Teknologi Sepuluh November. Surabaya. 2011.

Sassner P, Martensson CG, Galbe M, Zacchi G. Steam Pretreatment of $\mathrm{H}_{2} \mathrm{SO}_{4^{-}}$impregnated Salix for Production of Bioetanol. J. Bioresource Technol. 2008.

Setyaningsih LWN, Rizkiyaningrum UM, Andi R. Pengaruh Konsentrasi Katalis dan Reusability Katalis pada Sintesis Triasetin dengan Katalisator Lewatit. Teknoin, 2017; 23(1): 56-62.

Sugiharto PE. Analisis Kuantitatif Kadar Etanol dari Bonggol Pisang oleh Saccharomyces cerevisiae. Skripsi. Fakultas MIPA, Universitas Brawijaya, Malang. 1991.

Sumada K, Tamara PE, Alqani F. Kajian Proses dari Limbah Batang Tanaman Manihot esculenta crantz yang Efisien. Jurnal Teknik Kimia. 2011; 5(2): 434 - 438.

Susmiati Y. Prospek Produksi Bioetanol dari Limbah Pertanian dan Sampah Organik. Industri. Jurnal Teknologi dan Manajemen. 2018; 7(2): 67-80.

Taherzadeh MJ, Karimi K. Acid-Based Hydrolysis Processes for Ethanol from Lignocellulosic Materials: A Review. Bio Resources. 2007; 2: 472-499.

Wardani AK, Kusumawardini I. Pretreatment Ampas Tebu (Saccharum oficinarum) sebagai Bahan Baku Bioetanol Generasi Kedua, (Online), http://tehapeub.net/ejurnal/715d7Indah-K.pdf. 2012.

Zabed H, Sahu JN, Suely A, Boyce AN, Faruq G. Bioethanol Production from Renewable Sources: Current Perspectives and Technological Progress. Renewable and Sustainable Energy Reviews. 2017; 71:475-501. 